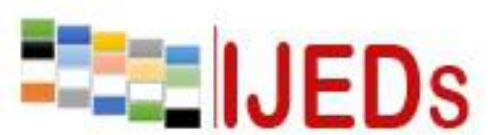

http://ijeds.ppj.unp.ac.id/index.php/IJEDS

\title{
USE OF THE PROBLEM BASED INSTRUCTION MODEL ON ACTIVITIES AND RESULTS OF INTEGRATED THEMATIC LEARNING STUDENTS IN CLASS V
}

\author{
*Sonia Septi Gamandari \\ Graduate Program of Education Faculty of Science, Universitas Negeri Padang, \\ Indonesia \\ Email: soniasepti291@gmail.com
}

*Corresponding Author, Received: November 12, 2018, Revised: December 10, 2018, Accepted: December 21, 2018

\begin{abstract}
This research is motivated by the lack of teachers' ability to design the use of problem based instruction models on students' thematic learning outcomes, planning the use of problem based instruction models for students' thematic learning outcomes. The purpose of this study is to increase the use of problem based instruction models for student thematic learning outcomes problem based instruction model of the results of students' thematic learning and improving student learning outcomes using the Problem Based Instruction Model. This type of research is a field research with a descriptive qualitative method. The results showed that the use of the Problem Based Instruction model in the teaching and learning process can improve student learning outcomes. Conclusion of the form of planning using the Model Problem Based Instruction The teacher has prepared the RPP so that learning is more directed. Use of Problem Based Instruction Models can improve student learning outcomes the teacher in using the model based instruction problem the time used is very limited
\end{abstract}

\section{Keywords: Problem Based Instruction (PBI) Learning Outcomes}

\section{INTRODUCTION}

Thematic learning whose implementation is no longer separated but becomes a holistic and integralistic one. Tyler in Jacobs (1989) has suggested that separate learning be more integrated, because if experiences are not linked, learners will develop learning activities that are not related to one another and are not effective in dealing with everyday life. Thematic learning needs to be prepared to the maximum, various variations of activities using various learning models, the learning model serves as a guide for the instructors in carrying out the learning process. Thematic learning 


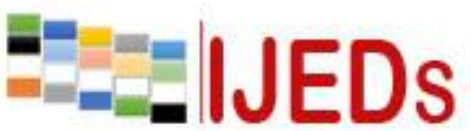

http://ijeds.ppj.unp.ac.id/index.php/IJEDS

emphasizes the involvement of students in the learning process or actively directs students in the learning process.

With thematic learning students gain direct experience and are trained to find their own various knowledge that is learned holistically, meaningfully, authentically and actively. One model that can improve students' understanding and activeness in the 2013 curriculum is to use the problem based instruction (PBI) learning model. in learning is believed to be able to improve learning outcomes in students. This PBI learning model is a comprehensive program in the higher classes in schools. Problem Based Instruction is a model of teaching with student learning approaches to authentic problems. Authentic problems can be interpreted as a problem that students often find in everyday life.

\section{METHOD}

This type of research is a field research with a descriptive qualitative method. Sugiyono stated Qualitative research was "a naturalistic research method because its research was carried out in natural conditions". Reinforced according to Bogdan and Taylor in Moleong's book defines "qualitative methodology as a research procedure that produces descriptive data in the form of written words from people and observed behaviors." So the data obtained from this study is an elaborate attempt of facts , reality, or an event.

\section{RESULTS AND DISCUSSION}

Problem based learning model is a learning model based on many problems requires authentic investigations, namely investigations that require real solutions to real problems "Problem Based Instruction is a model of teaching with student learning approaches to authentic problems. Authentic problems can be interpreted as a problem that students often find in everyday life. According to Dewey learning based on problems is the interaction between stimulus and response, is a relationship between two directions of learning and the environment. The environment gives input to students in the form of help and problems, while the brain's nervous system functions to interpret the aid effectively so that the problems faced can be investigated, assessed, analyzed. 


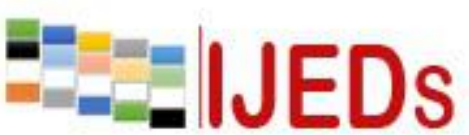

http://ijeds.ppj.unp.ac.id/index.php/IJEDS

"In other words this learning model raises an actual problem as a challenging and interesting learning. Students are expected to learn to solve these problems fairly and objectively. "

Submitting questions or problems. Instead of organizing around certain academic principles or skills, problem-based learning organizes teaching around questions and problems that are both socially important and personally meaningful to students. Focusing on interdisciplinary linkages. Even though problem-based learning may be centered on a particular subject, the problem to be investigated has been chosen so that in solving it, students review the problem from many subjects. Authentic inquiry. Problem based learning requires students to carry out authentic investigations to find real solutions to real problems. Problem based learning requires students to produce certain products in the form of real wealth to solve the same problem found.

So the characteristics of the problem based introduction model are: covering a question or problem submission, concentrating the inter-disciplinary linkages. Authentic inquiry, producing work and demonstration Problem based learning is not designed to help teachers provide as much information to students.

Problem Based Introduction is not designed to help teachers provide as much information as possible to students, but is intended to help students develop thinking skills, problem solving, and intellectual skills, learn various roles of adults through their involvement in real or simulated experiences; and become autonomous and independent learners. Many problems exist in the student environment. With the learning of Problem Based Instruction can increase the sensitivity of students to the situation environment. This sensitivity is not only manifested in feelings but there are practical steps they can take to provide solutions to the problem.

Problem based teaching is not designed to help teachers provide as much information to students. According to Sudjana, the special benefits obtained from the Dewey method are problem solving methods. The teacher's job is to help students form tasks, and not present lesson assignments

The principle of learning is to do, do to change behavior, conduct activities or activities. It can be said that without activity, the learning process cannot take place properly. According to Dimyati (2010: 114) "The activity of students in the learning 


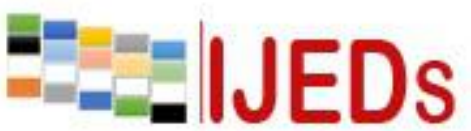

http://ijeds.ppj.unp.ac.id/index.php/IJEDS

process takes various forms of activities, from physical activities that are easily observed to psychic activity that is difficult to observe".

Furthermore Uno (2011) states "to create active learning, one of which is children learn from their experiences, besides children must learn to solve problems that they get". Large Dictionary of Indonesian Language (1999) states "Activity means activity, activity or busyness. Rousseau in (Sardiman, 2001) provides an explanation that, "in the learning process all knowledge must be obtained by working alone, with self-created facilities, both spiritually and technically".

This shows that everyone who learns must be active on their own and without any activity the learning process is not possible. Many types of activities students can do at school. These activities are not only enough to listen and take notes (Erianjoni, 2016). Learning outcomes are a benchmark to see the success of students in mastering the subject matter delivered during learning. This will be determined by the occurrence of changes in behavior to students after the learning process ends.

As stated by Suprijono (2009) that "Learning outcomes are patterns of actions, values, understandings, attitudes, appreciation and skills". Hamalik (2008) states "Learning outcomes are behaviors that arise, for example from not knowing to knowing, emerging new questions, changes in the stages of habitual skills, ability to appreciate, development of social, emotional and physical growth". Thematic learning outcomes referred to here are cognitive learning outcomes obtained by students before and after experiencing an integrated thematic learning process using the PBI. Learning for elementary school students (I-VI) is carried out with thematic learning.

According to Rusman (2011) suggests thematic learning is "integrated learning which is a learning system that allows students, whether individually or in groups, actively explore and discover the concepts and principles of wisdom in a holistic, meaningful and authentic manner. In line with that, Sutirjo in Suryosubroto, 2009), states "Thematic learning is an effort to integrate knowledge, skills, values or attitudes of learning, as well as creative thinking using themes". 


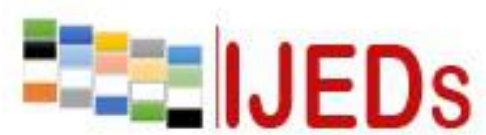

http://ijeds.ppj.unp.ac.id/index.php/IJEDS
International Journal of Educational Dynamics

Vol. 1 No. 1 (pp. 264-269) December 2018

p_ISSN 2655-4852

e ISSN 2655-5093

\section{CONCLUSION}

Problem based learning model is a learning model that is based on the many problems that require authentic inquiry, namely investigations that require real solutions to real problems. "Problem Based Instruction is a model of teaching with student learning approaches to authentic problems. Thematic learning is integrated learning that uses themes, to link several subjects that have to do with everyday life so as to provide a meaningful experience for students.

\section{REFERENCES}

Abbas, S. 2006. Effective Indonesian Language Learning in Primary Schools. Jakarta: Bumi Aksara.

Abimanyu, S. 2008. Learning Strategies. Jakarta: Directorate General. Higher Education, Ministry of National Education.

Arikunto, S. 2010. Research Procedure, Yogyakarta, Rineka Cipta

Bungin Burhan, 2008, Qualitative Research Methodology, Jakarata: Raja Grafindo Persada.

Erianjoni. 2016. Integrasi Nilai-nilai Kearifan Lokal Minangkabau ke dalam Materi Ajar Sosiologi dalam Pembentukan Karakter Peserta Didik. Jurnal Tingkap. Volume 11 No. 1 (2016).

Ministry of National Education. 2006. Education Unit Level Curriculum. Jakarta: Ministry of National Education.

Hamalik, O. 2007. Curriculum and Learning. Jakarta: Bumi Aksara.

Kunandar. 2008. Professional Teachers for KTSP Implementation and Preparation for Facing Teacher Certification. Jakarta: PT Grafindo Persada.

Mudjono, D. 2006. Learning and Learning. 6th print. Jakarta: Rineka Cipta.

Muslich, M. 2009. Competency and Context Based Learning. Jakarta: Bumi Aksara. 2010. Develop thematic learning. Jakarta: Kencana.

Sugiyono. 2008, Qualitative Quantitative Research Methods and R \& D, Bandung, Alfabeta trianto, 2009, designed an Innovative Learning Model -Progresif, Jakarta: PT fajar interpratama

Yusuf, A. M. 2007. Research Methodology. Padang: UNP Press.

Yusuf, A. M. 2013. Research Methods. Padang: UNP Press

Purwanto, N. 2006. Teaching Evaluation Principles and Techniques. Bandung: PT Remaja Rosdakarya.

Rusman. 2011. Learning Models Developing Teacher Professionals. Jakarta: Rajawali Press.

Sagala, S. 2008. Concepts and Meanings of Learning. Bandung: Alfabeta.

Sanjaya, V. 2008. Learning Strategies Oriented to Educational Process Standards. Jakarta: Kencana Prenada Media Group.

Sugiyoo. 2010. Qualitative Quantitative Research Methods and R \& D. Bandung: Alfabeta. 
International Journal of Educational Dynamics

$=-=\mid$ IJEDS

Vol. 1 No. 1 (pp. 264-269) December 2018

http://ijeds.ppj.unp.ac.id/index.php/IJEDS

p_ISSN 2655-4852

e ISSN 2655-5093

Suprihatiningrum, J. 2016. Theory \& Application Learning Strategies. Yogyakarta: Ar-Ruzz Media.

Trianto. 2011. Integrated Learning Model: Concept, Strategy, and Implementation in the Education Unit Level Curriculum (KTSP). Jakarta: Bumi Aksara.

Yani, A. 2014. 2013 Curriculum Mindset. Bandung. Alfabeta CV. 